\title{
Scenario of heavy metal contamination in agricultural soil and its management
}

\author{
A. K. Chopra, Chakresh Pathak* and G. Prasad ${ }^{1}$ \\ Department of Zoology and Environmental Science \\ ${ }^{1}$ Department of Botany and Microbiology, Gurukula Kangri University, Haridwar-2494404 (Uttarakhand), INDIA \\ *Corresponding author. E-mail: chakreshpathak@yahoo.co.in
}

\begin{abstract}
Soil is a complex structure and contains mainly five major components i.e. mineral matter, water, air, organic matter and living organisms. The quantity of these components in the soil does not remain the same but varies with the locality. Soil possesses not only a nucleus position for existence of living being but also ensures their future existence. Therefore, it is essential to make an adequate land management to maintain the quality of soil in both rural and urban soil. The presence of different kinds of heavy metals such as $\mathrm{Cd}, \mathrm{Cu}, \mathrm{Mn}, \mathrm{Bi}$ and $\mathrm{Zn}$ etc. in trace or in minimum level is a natural phenomenon but their enhanced level is an indicator of the degree of pollution load in that specific area. The precise knowledge of these kinds of heavy metals, their forms and their dependence on soil provides a genuine base for soil management. The heavy metals have potent cumulative properties and toxicity due to which they have a potential hazardous effect not only on crop plants but also on human health. The metal contaminants can be reduced by immobilization of contaminants using macrophytes and also by using genetically engineered microorganisms.

Keywords: Heavy metal, Contamination, Agricultural soil
\end{abstract}

\section{INTRODUCTION}

Albeit the development of scientific and industrial technology has provided not only a large number of benefits to the society, it has also generated different kinds of several undesirable environmental pollutants including heavy metals. Heavy metals are being generated by different kinds of industries and reaching in the soil through industrial effluent. The quality and concentration of the heavy metals varies from industry to industry and has a direct concern with nature of the product.

Heavy metals are the stable metals or metalloids whose density is greater than $4.5 \mathrm{~g} / \mathrm{cm} 3$, namely $\mathrm{Pb}, \mathrm{Cu}, \mathrm{Ni}, \mathrm{Cd}$, $\mathrm{Zn}, \mathrm{Hg}$ and $\mathrm{Cr}$ etc. They are stable and cannot be degraded or destroyed, and therefore they tend to accumulate in soils and sediments. There are several sources of heavy metals in the environment: 1) air which contains mining, smelting and refining of fossil fuels, production and use of metallic commercial products and vehicular exhaust, 2) water having domestic sewage, sewage and industrial effluents, thermal power plants and atmospheric fallout and 3) soil like - agricultural and animal wastes, municipal and industrial sewage, coal ashes, fertilizers, discarded manufacture goods and atmospheric fallout.

Soil pollution with heavy metals has become a critical environmental concern due to its potential adverse ecological effects. Heavy metals occur naturally at low concentrations in soils. However, they are considered as soil contaminants due to their widespread occurrence, acute and chronic toxicity. These metals are extremely persistent in the environment. They are non-biodegradable, non thermo-degradable and thus readily accumulate to toxic levels. Since they do not break down, they might affect the biosphere for a long time. It is known that heavy metals form an important polluting group. They have not only toxic and carcinogenic effect but also tend to accumulate in living organisms. The irrigation of wastewater (industrial, municipal and house hold), sewage-sludge and dumped solid wastes on soils has been widespread in agricultural areas. The heavy metals also occur naturally, but rarely at toxic level.

Heavy metals come from local sources mostly from the industries (non-ferrous industries, power plants, iron, steel and chemical industries), agriculture (irrigated with polluted water, use of mineral fertilizers especially phosphates, contaminated manure, sewage sludge and pesticides containing heavy metals), from waste incineration, burning of fossil fuels and road-traffic. Researchers have made an important contribution both in India and abroad to investigate the impact of effluent storage / irrigation / drainage on soil related with heavy metal contamination and their accumulation in the plant system and lastly in the product.

Aydinalp and Marinova (2003) observed the soil of Turkey -Bulgaria for the presence of heavy metals and found their higher values indicating metallic soil pollution. However, these heavy metals were found in minimum levels in the plants grown in that specific area. Rahmani (2007) reported that organic contents were higher in the crop irrigated with municipal waste water while heavy 
metals i.e. Fe, $\mathrm{Mn}, \mathrm{Cd}, \mathrm{Zn}$ were found higher than the normal range. Mustafa et al. (2006) made an extensive study on impact of irrigation of sewage along the main discharge channel of Konya, Iran and found increased concentration of heavy metals such as $\mathrm{Zn}, \mathrm{Cu}, \mathrm{Cr}, \mathrm{Mn}, \mathrm{Cr}$, $\mathrm{Ni}, \mathrm{Pb}$ and $\mathrm{Cd}$ in fertile soil and showed negative effect on plant system. Mishra and Tirpathi (2008) studied heavy metals contamination of soil and their bioaccumulation in the agricultural products especially vegetables irrigated with treated waste water in Varanasi, India and found that metals concentration of Cd-3.4, Cr-56.3, Pb-123.5, Zn-122.3 and $\mathrm{Cu}-77.8 \mathrm{mg} / \mathrm{kg}$ each in soil in the selected sites . Rattan et al. (2005) studied the long term impact of irrigation with sewage effluents on heavy metal content in soil, crops and ground water. Masto et al. (2008) observed change in soil quality indicators under long term sewage irrigation in a sub-tropical environment and concluded that the longterm sewage irrigation resulted into significant build-up of DTPA extractable $\mathrm{Zn}(314 \%), \mathrm{Cu}(102 \%), \mathrm{Fe}$ (715\%), $\mathrm{Mn}(197.2 \%), \mathrm{Cd}(203 \%), \mathrm{Ni}(1358 \%)$ and $\mathrm{Pb}(15.2 \%)$ when compared with the metals in adjacent rain fed reference soil.

Sidhu and Narwal (2004) studied the interactive effects of organic materials and lead on maize yield and different fractions of lead in soil. Lokeshwari and Chandrappa (2006) studied the impact of heavy metal contamination of Bellandur lake on soil and cultivated vegetation and concluded that the sewage is the main source of pollution of this water body. The irrigation with sewagecontaminated water containing variable amount of heavy metals leads to increase in concentration of metals in the soil and vegetation.

Traffic and industrial activities in the new urban areas have been increasing and have caused heavy metal contamination in urban and suburban soils. Urban soils are the recipients of large amount of heavy metals from a variety of sources. Heavy metals in soil may be found in one or more of the following forms: a) dissolved (in soil solution), b) exchangeable (in organic and inorganic components), c) as structural components of the lattices of soil minerals and d) as insoluble precipitates with other soil components. The first two forms are available to the plants while the other two are potentially available in the longer term (Aydinalp and Marinova, 2003).

The hazards of wastewater and solid waste used in urban and peri-urban agriculture (UPA) have been categorized into three groups: biological agents, chemical and physical hazards (Cole et al., 2003). Biological agents include bacteria, helianthus, viruses, protozoa and micro-fauna while physical hazards include sharp objects, psychosocial discrimination, insecurity and land tenure. Chemical contamination is a potential risk associated with waste reuse, notably in municipal solid waste and wastewater, especially if it is of industrial origin. Chemical hazards include chemical agents such as heavy metals, nutrients such as nitrogenous compounds, phosphorus compounds, minerals, insecticides, pesticides, fertilizers, fungicides, herbicides and organic hazards. The contamination of soils by chemicals, the potential uptake by crops, and the possible chronic and long-term toxic effects in humans are discussed by Chang, et al. (1995); and Birley and Lock (1999).

Recently pollution of general environment has increasingly gathered a global interest. In this respect, contamination of agricultural soils with heavy metals has always been considered a critical challenge in scientific community. Heavy metals are generally present in agricultural soil at low levels. Due to their cumulative behavior and toxicity, they have a potential hazardous effect not only on crop plants but also on human health. Various industries are playing a key role in this context by discharging a large amount of effluents on the land soil.

\section{TYPES OF HEAVY METALS CONTAMINATION IN SOIL}

Lead: Lead is naturally occurring, but is often released into the environment from artificial sources. It has been mined, smelted, refined and used for last hundreds of years. It has also been used as an additive in paints and gasoline, leaded pipes, solders, crystals and ceramics (Paz-Alberto et al., 2007).It may be commonly found in feldspars, micas and also in phosphate minerals, such as apatite and the plumb gummite group of minerals due to the isomorphous substitution of lead for $\mathrm{K}$ and $\mathrm{Ba}$ and sometimes $\mathrm{Ca}$ in the minerals. Lead concentrations in uncontaminated soils are generally ca. $20 \pm 50 \mathrm{mg} / \mathrm{kg}$ (Norrish, 1968 and Nriagu, 1978), but some soils such as black organic shales may have naturally higher concentrations.

In areas of high vehicular traffic, close to urban centres, and/or close to smelters, the atmospheric deposition may be high. Lead addition to soils in agricultural herbicides/ pesticides has been significant in the past with some orchard soils receiving up to $10 \mathrm{~kg} \mathrm{~Pb} /$ year resulting in lead concentration in some of these soils exceeding 500 mg kgÿ1 (Merry et al., 1983). However, these practices have now been largely stopped.

Addition of sewage sludge to agricultural soils may also add significant amount of lead to soil depending on the source of the sludge. Input of lead to agricultural soil occurs through atmospheric deposition of lead derived from combustion of gasoline containing lead additives and from fugitive emissions from nonferrous metal smelting (Alloway, 1990). The success of re-vegetation should overcome two major problems-toxicity of heavy metals and deficiency of major nutrients (Bradshaw 1997). Open-cast mining activities usually yield extremely harsh 
surroundings, including large quantities of waste materials, higher concentrations of pollutants which make the soil severely infertile. These adverse factors usually inhibit plant establishment and growth. The re-vegetation of mined land is necessary for both pollution control and the long-term stability of the soil surface (Xia, 2004).

More than 60,000 tons of lead is annually deposited in U.S. shooting ranges (Craig et al., 1999). Shooting activities have been reported to be the largest contributors of lead to the environment (USGS, 2002). The most commonly applied pozzolanic materials are portland cement, lime, and/or fly ash (Palomo and Palacios, 2003; Dermatas and Meng, 2003; and Terzano et al., 2005).The lead in fuels contributes to air pollution, especially in urban areas. Soil near highways, freeways, and smelting facilities have higher levels of lead than the soil in other areas because of their exposure to lead dust, which accumulates over time (Ona et al., 2006). The impact of mineral extraction occurs not only in the mine zone, but also in the surrounding areas when polluted sediments are carried out by rivers and runoff (Jiménez-Cárceles et al., 2008).

Cadmium: Cadmium concentrations in crystal rocks vary from one to $90,000 \mathrm{mg} / \mathrm{kg}$ (Page et al., 1981; Cook and Freney, 1988; and Kabata-Pendias and Pendias, 1992) with igneous and metamorphic rocks generally having lower cadmium concentrations than the sedimentary deposits. Anthropogenic addition of cadmium to soil occurs via short- or long-range atmospheric deposition, addition in fertilizers/manures and in municipal sewage wastes (effluents and biosolids), urban composts and industrial sludges. Atmospheric cadmium is derived from mining and smelting of nonferrous metals, the production of iron and steel, combustion of fossil fuels and waste incineration. In fertilizers, cadmium is found predominantly in phosphatic fertilizers due to its presence as an impurity in all phosphate rocks.

The contribution of the atmosphere, fertilizer, sludge, manure or compost to the total annual cadmium addition to soils varies widely among the countries and the regions within countries (Jensen and Bro-Rasmussen, 1992; and McLaughlin et al., 1996). In less industrialized agricultural regions or countries (e.g. Australia), atmospheric deposition of cadmium is minimal . Cadmium is an important toxic heavy metal and the warning of health risks from cadmium pollution was issued initially in the 1970s. Increased concentrations of cadmium in agricultural soils are known to come from human activities (Taylor, 1997) such as the application of phosphate fertilizer, sewage sludge, wastewater and pesticides (Chen et al., 1997; Qadir et al., 2000; de Meeus et al., 2002 and Kara et al., 2004), mining and smelting of metalliferous ores with high cadmium content (Tembo et al., 2006 and Kovacs et al., 2006), and from traffic (Nabulo et al., 2006).
Mercury: Mercury occurs in a wide range of minerals in the earth's crust, with average crusted concentrations of mercury-0.08 mg/kg (Mason and Moore, 1982). It is also associated with $\mathrm{Zn}, \mathrm{Fe}$ and other complex sulphides (Steinnes, 1990). Sedimentary rocks generally have higher mercury concentrations than igneous rocks (KabataPendias and Pendias, 1992). Mercury is inadvertently added to soils in fertilizer, limestone, natural gypsum, phosphogypsum, manure (especially of marine origin), sewage sludge, etc. and intentionally in fungicides containing mercury (Andersson, 1979). Mercury concentrations in limestone are generally <20 mg kgÿ1, animal manures may have concentrations of the order of $100 \mathrm{mg}$ kgÿ1, while typical concentrations of mercury in sludge may range from 5 to $10 \mathrm{mg} / \mathrm{kg}$, and occasionally values of up to $100 \mathrm{mg}$ kgÿ1 are reported (Steinnes, 1990). The emission of mercury from chlor-alkali plants contributes significantly to the total mercury emission from anthropogenic sources. There is also a risk of direct discharge of elemental mercury to the soil during the active period of the plant and in connection with closure of the plant. Once deposited in the soil, mercury can participate in several chemical and biological processes, such as redox reactions, methylation processes, adsorption processes and complexation to soil humic acids or to inorganic ligands such as chloride, sulfate or (hydr)oxide ions. Phosphate rocks and hence, phosphatic fertilizers generally have low mercury concentrations $(<0.4 \mathrm{mg}$ kgÿ 1$)$ (Sauerbeck, 1993).

Arsenic : Arsenic is widely distributed into the nature in form of either metalloids or chemical compounds, which causes a variety of pathogenic conditions including cutaneous and visceral malignancies (Matsui et al., 1999) and it is of great environmental concern due to extensive contamination of thousands of sites around the world resulting from a variety of human activities (Sheppard, 1992; Simón et al., 1999 and Feller, 2000). The principal causes of elevated soil aresenic are the historically widespread use of arsenic compounds as insecticides, herbicides, and defoliants for agricultural production. These include inorganic salts and various organic compounds of both, arsenite (As[III]) and arsenate (As[V]). High levels of arsenic occur naturally in some sedimentary rocks and in geothermally active areas (Peterson et al., 1981). Mining and smelting of nonferrous metals can lead to significant soil contamination by runoff from spoil-tips and tailings, and from smelter emissions. Arsenic is widely used as a feed additive for poultry and swine production and the resulting manures can represent a significant source of soil arsenic. Arsenic from phosphate fertilizers, from fossil-fuel combustion (including land disposal of fly ash), and from municipal sewage sludges are generally considered to be relatively minor sources of 
soil arsenic (O’Neill, 1990). It shows toxicity even at low exposure (Dikshit et al., 2000) and causes black foot disease (Lin et al., 1998). Arsenic contamination is also associated with coal-mines (Manahan 1997). It exists in two forms i.e. As (V) and As (III), former is the predominant form in the environment since As (III) is oxidized by atmospheric oxygen (Bissen and Frimmel, 2000). Heavy metals including arsenic cannot be degraded easily and their cleanup usually requires their removal (Lasat, 2002).

Selenium: - The primary cause of elevated soil selenium is its natural occurrence, most often in sedimentary rocks (especially some cretaceous shales) from which seleniferous soils wither (Mayland et al., 1989). Irrigated agriculture may redistribute and concentrate selenium that is by disposal of saline drainage water into closed impoundments where further evaporative concentration takes place (Mayland et al., 1989). Natural soil occurrence may also coincide with increases due to agricultural practices as described for the Chinese case of human selenium toxicosis. Most coals are insufficiently higher in selenium to cause major problems with fly-ash disposal, and other sources such as phosphorous fertilizers and sewage sludges make minor contributions of Se to most soils (Peterson et al., 1981 and Mayland et al., 1989). Soils deficient in selenium with respect to human and/or livestock nutrition are formed from low-selenium igneous and metamorphic rocks and are particularly prevalent in parts of Scandinavia, China and New Zealand (Combs and Combs, 1986).

\section{SOURCES AND RISKS OF HEAVY METALS} CONTAMINATION

Soil pollution comprises the pollution of soils with materials, mostly chemicals that are out of place or are present at concentrations higher than normal which may have adverse effects on humans or other organisms. Soil pollution is also caused by means other than the direct addition of xenobiotic (man-made) chemicals such as agricultural runoff waters, industrial waste materials, acidic precipitates, and radioactive fallout. Both organic (those that contain carbon) and inorganic (those that don't) contaminants are important in soil. The most prominent chemical groups of organic contaminants are fuel hydrocarbons, polynuclear aromatic hydrocarbons (PAHs), polychlorinated biphenyls (PCBs), chlorinated aromatic compounds, detergents, and pesticides. Inorganic species include nitrates, phosphates, and heavy metals such as cadmium, chromium and lead; inorganic acids; and radionuclides (radioactive substances). Among the sources of these contaminants are agricultural runoffs, acidic precipitates, industrial waste materials and radioactive fallout.

Major contributions of heavy metal contamination in the soil are by irrigation with discharge of industrial effluent and domestic sewage directly on earth surface. Both kinds of effluent (low and treated) contains major pollutants especially from the industries usage in metallic work. Trend of sewage irrigation has been forced due to two reasons i.e. due to regular shortage of fresh water availability and secondly to solve /manage the liquid waste problem. The fulfillment of the basic need (food required) of society and to facilitate more amenities (luxury product) has caused excess generation of heavy metals which ultimately find their way on soil. Variability of heavy metal contaminants both in their forms and quantity may be due to specific conditions. Some of the major important works made by the researcher on this approach in India can be quoted. Gupta et al. (2007) found that leather industries (Tanneries) located at Jajmau, Kanpur, are the major sources of heavy metal contaminations in the agricultural soil in the surrounding areas where treated effluent has been used for irrigation. Rattan et al. (2005) reported that under Keshopur effluent irrigation scheme, in Delhi, India for 20 years resulted in to significant build up of DTPA extractable Zn (208\%), Cu (170\%), Fe (170\%), $\mathrm{Ni}(63 \%)$, and $\mathrm{Pb}(29 \%)$ in sewage irrigated soils.

Normally, domestic waste has lower heavy metal contents than industrial waste. Industrialized societies produce large amount of waste and one of the options for its disposal is through application on agricultural soil. Soils irrigated by wastewater accumulate heavy metals such as $\mathrm{Cd}, \mathrm{Zn}, \mathrm{Cr}, \mathrm{Ni}, \mathrm{Pb}$ and $\mathrm{Mn}$ in surface soil. When the capacity of the soil to retain heavy metals is reduced due to repeated use of wastewater, soil can release heavy metals into ground water or soil solution available for plant uptake. The long-term use of sludge can cause heavy metal accumulation in soils (López-Mosquera et al., 2000). Even after short-time application of biosolids, the levels of heavy metals in soils can increase considerably. Oliveira and Mattiazzo (2001) observed increase in $\mathrm{Cu}, \mathrm{Ni}, \mathrm{Cr}$ and $\mathrm{Zn}$ concentration in soils amended for two years with biosolids. Heavy metals can also contaminate the food chain and reduce crop yields (Obrador et al., 1997 and Wang et al., 2003). The practice of wastewater irrigation is widely adopted by resource poor farmers, but the potential health risks are often overlooked. Wastewater is often contaminated with industrial effluent that contains high levels of heavy metals. Dietary intake of heavy metals is a substantial risk to the health of families who depend upon the use of contaminated irrigation water to grow crops to meet their food requirements.

Soil has traditionally been an important medium for waste disposal (Nyles and Ray, 1999; and Anikwe and Nwobodo, 2002). Municipal waste dump soils are always higher in organic matter (Anikwe and Nwobodo, 2002).In the long term, the use of municipal solid waste (MSW) compost may also cause a significant accumulation of $\mathrm{Zn}, \mathrm{Cu}, \mathrm{Pb}$, 


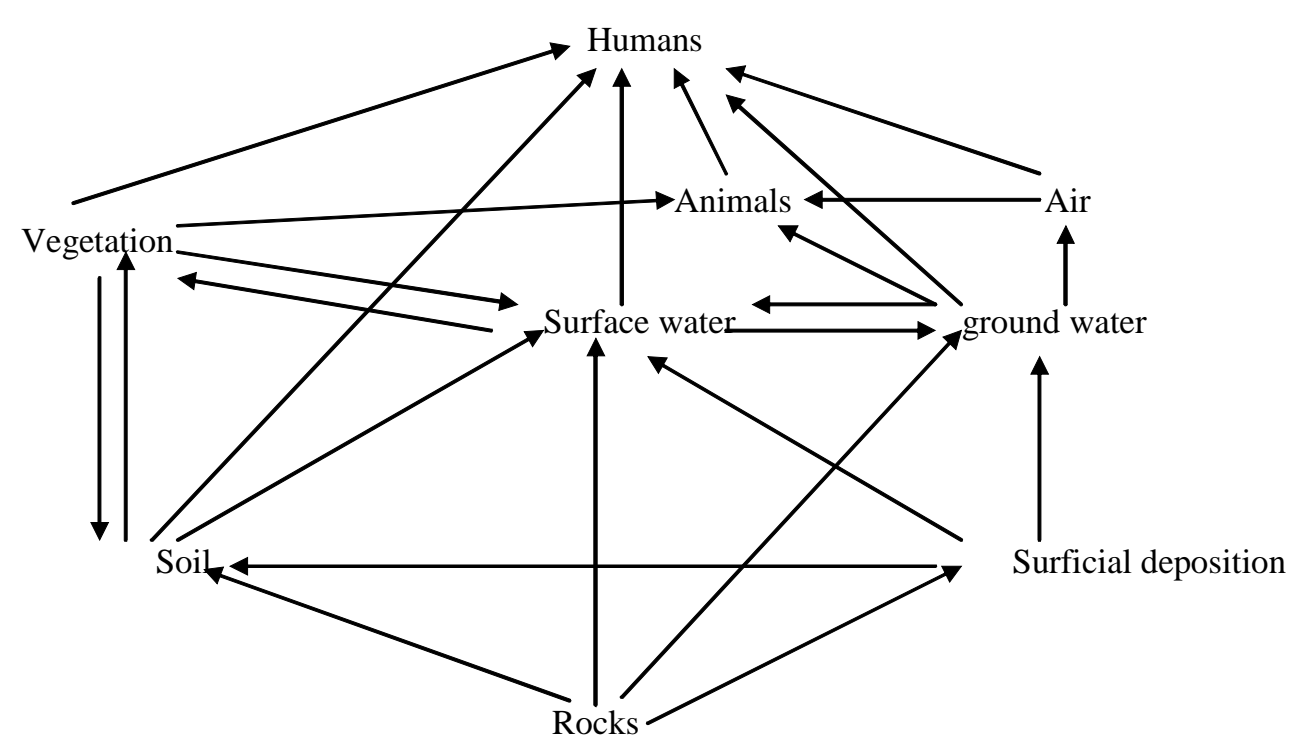

Fig. 1. Potential pathways for toxic elements to become concentrated in plants, soil, animals and humans. (Sources: J.J Connor, 1990. U.S.Geological Survey circular1033.p.61)

$\mathrm{Ni}$ and $\mathrm{Cd}$ in the soil and plants. Contamination of soils by potentially toxic elements (e.g. $\mathrm{Zn}, \mathrm{Cu}, \mathrm{Ni}, \mathrm{Pb}$ and $\mathrm{Cd}$ ) from amendment of sewage sludge and MSW compost is subject to strict control within the European community in relation to total permissible metal concentration, soil properties and intended use.

Heavy metals as micronutrients appear essential contents for biological system which are being obtained from soil through agricultural products as these are the major sources of bioaccumulation of different kinds of heavy metals and are transferred to the human system. We always ingest them to some extent in food and water, and we breathe them in the air. In addition to their essentiality for plant growth and/ or human nutrition, some micronutrient elements may also be toxic to both animals and humans at higher concentrations e.g. $\mathrm{Cu}, \mathrm{Cr}, \mathrm{F}, \mathrm{Mo}, \mathrm{Ni}, \mathrm{Se}$ and $\mathrm{Zn}$. Other trace elements e.g. As, $\mathrm{Cd}, \mathrm{Hg}$ and $\mathrm{Pb}$ may also inadvertently enter the food chain and pose health risks to humans and animals. Potentially these heavy metals can accumulate in the soil and in plants, and may pose a potential health risk to people who breathe or especially swallow contaminated soil or eat contaminated vegetables. Although plants always absorb trace elements to some extent, in nearly all instances the quantities they take up are too insignificant to cause alarm.

\section{MANAGEMENT OF CONTAMINATED SOIL}

Soil and crop management methods can help in preventing the uptake of pollutants by plants, leaving them in the soil. The soil becomes the sink, breaking the soil-plant animal or human cycle through which the toxins exert their toxic effects (Brady and Weil, 1999).

The soil's ability to immobilize heavy metals increases with rising $\mathrm{pH}$ and peaks under mildly alkaline conditions. Heavy metals mobility is related to their immobilization in the solid phase (Fuller,1977). He considered that in acid soils ( $\mathrm{pH}$ 4.2-6.6) the elements $\mathrm{Cd}$, Ni, and $\mathrm{Zn}$ are highly mobile. $\mathrm{Cr}$ is moderately mobile; and $\mathrm{Cu}$ and $\mathrm{Pb}$ practically immobile and in neutral to alkaline ( $\mathrm{pH}$ 6.7-7.8), Cr is highly mobile whereas $\mathrm{Cd}$ and $\mathrm{Zn}$; and $\mathrm{Ni}$ are moderately mobile and immobile respectively.

Certain management practices will not only remove the heavy metal contaminants, but will also help to immobilize them in the soil and reduce the potential of adverse effects from the metals. Cationic metals are more soluble at lower $\mathrm{pH}$ level, therefore, increasing the $\mathrm{pH}$ in soil makes them less available to plants and therefore less likely to be incorporated in their tissues and ingested by humans. Raising $\mathrm{pH}$ has the opposite effect on anionic elements. Drainage improves soil aeration and allows metals to oxidize, making them less soluble. Therefore when aerated, these metals are less available. The opposite is true for chromium, which is more available in oxidized forms. Active organic matter is effective in reducing the availability of chromium.

Heavy phosphate applications reduce the availability of cationic metals, but have the opposite effect on anionic compounds like arsenic. Care should be taken with phosphorus applications because high level of phosphorus in the soil can result in water pollution.Plants translocate larger quantities of metals to their leaves then to their fruits or seeds. The greatest risk of food chain 
contamination is in leafy vegetables like lettuce or spinach. Another hazard is forage eaten by livestock.

\section{PLANTS IN MANAGEMENT OF METAL CONTAMINATED SOIL}

Plants have been used to stabilize or remove metals from soil and water. It has been demonstrated that plants are effective in cleaning up contaminated soil (Wenzel et al., 1999). Phytoremediation is a general term for using plants to remove or degrade different kinds of soil pollutants such as heavy metals, pesticides, solvents, crude oil, polyaromatic hydrocarbons, and landfill leacheates e.g. prairie grasses can stimulate breakdown of petroleum products. In phytoremediation, accumulation and distribution of heavy metals in plant tissue are important aspects to evaluate the role of plants in remediation of metaliferous soil (Friedland, 1889). Wildflowers have been used to degrade hydrocarbons from an oil spill in Kuwait. Hybrid poplars can remove ammunition compounds such as TNT as well as high nitrates and pesticides (Brady and Weil, 1999). In terms of stabilizing metal contaminated sites, a lower metal concentration in shoot is preferred in order to prevent metal from entering to the ecosystem through food chain (Pichtel et al., 2000).It is most applicable where the agricultural crop is grown but at the same time it may not be suitable if the grown plants (herb and shrubs) have medicinal values and are used as therapeutant or protectant either in the form of shoots or roots which are used as raw material in order to prevent their circulation in the society. Yang et al. (2003) made a comparative study of three plant species i.e. Veteveria zizanioides, Sesbania restrata and $S$. sesban in a mining site containing heavy metals- $\mathrm{Pb}, \mathrm{Zn}, \mathrm{Cd}$ etc. and found that roots of all three plants species accumulated same concentration of heavy metals which was 3-4 times more in shoot of $S$. rostrata and $S$. sesban.

Metal contaminated soil can be remediated by chemical, physical and biological techniques. These can be grouped into two categories.

$\boldsymbol{E} \boldsymbol{x}$-situ method : It requires removal of contaminated soil for treatment and then returning the treated soil to the resorted site. The conventional ex-situ methods applied for remediating the polluted soils relies on excavation, detoxification and/or destruction of contaminants physically or chemically. As a result the contaminants undergoe stabilization, solidification, immobilization, incineration or destruction.

In-situ method : It is the remediation without excavation of contaminated site. Reed et al.,1992 defined in-situ remediation technology as destruction or transformation of the contaminant, immobilization to reduce bioavailability and separation of the contaminant from the bulk soil. In situ techniques are favoured over the ex-situ techniques due to their low cost and reduced impact on the ecosystem.

Immobilization of inorganic contaminants can be used as a remedial method for heavy metal contaminated soils. This can be achieved by complexing the contaminants, in soil by increasing the $\mathrm{pH}$ of soil by liming. Increased $\mathrm{pH}$ decreases the solubility of heavy metals like $\mathrm{Cd}, \mathrm{Cu}, \mathrm{Ni}$ and $\mathrm{Zn}$ in soil. Although the risk of potential exposure to plants is reduced, their concentration remains unchanged. Most of these conventional remediation technologies are costlier to implement and cause further disturbance to the already damaged environment. Plant based bioremediation technologies have been collectively termed as phytoremediation. This refers to the use of green plants and their associated microbiota for the in-situ treatment of contaminated soil and ground water.

The idea of using metal accumulating plants to remove heavy metals and other compounds was first introduced in 1983, but the concept has actually been implemented for the past 300 years. The generic term 'Phytoremediation' consists of the Greek prefix phyto (plant), attached to the Latin root remedium (to correct or remove an evil). This technology can be applied to both organic and inorganic pollutants present in soil (solid substrate), water (liquid substrate) and the air. The physico-chemical techniques for soil remediation render the land useless for plant growth as they remove all biological activities, including useful microbes such as nitrogen fixing bacteria, mycorrhiza, fungi, as well as fauna in the process of decontamination.

Recently, phytoextraction, the use of plants to extract toxic metals from contaminated soils, has emerged as a costeffective, environment-friendly cleanup alternative. Despite this tremendous potential, phytoremediation is yet to become a commercial technology. Progress in the field is precluded by limited knowledge of basic plant remedial mechanisms. In addition, the effect of agronomic practices on these mechanisms is poorly understood. Another limitation lies within the very biological nature of this novel approach. For example, potential for phytoremediation depends upon the interaction among soil, contaminants, microbes, and plants.

\section{MICROBIAL DEGRADATION OF HEAVY} METAL CONTAMINATIONS IN SOIL

The term biodegradation has been used to describe transformation of every type, including those that the yield product more complex than the starting material as well as those responsible for the complete oxidation of organic compounds to $\mathrm{CO}_{2}, \mathrm{H}_{2} \mathrm{O}, \mathrm{NO}_{3}$ and other inorganic components. The biodegradation of natural organic components by microorganisms seems to be a natural phenomenon. Large numbers of available synthetic compounds either have natural counterparts or are 
sufficiently similar to naturally occurring compounds to be subject to microbial metabolism. But the xenobiotic compounds have a different molecular structure and chemical bonds sequences which are not identified by the degrading enzyme because the microorganisms do not have that metabolic pathways which are needed for degradation of xenobiotic compounds. Several reports are available where the degradation of xenobiotics components has been done by certain microorganisms. A fungus Phanerochate has shown degradation of DDT (Bumps and Aust, 1989) and degradation of plastics specially polythene (Lee at el., 1991).

Spontaneous mutant of microorganisms increases the ability to utilize the xenobiotic compounds efficiently which may be helpful in this regard. Biotechnological approaches are in progress to develop genetically improved microbial stains for this remediation.Microbial activity and populations of cyanobacteria, Rhizobium leguminosarum bv.trifolii, mycorrhizae and the total microbial biomass have been adversely affected by metal concentrations which, in some cases, are below the European Community's maximum allowable concentration limits for metals in sludge-treated soils (McGrath et al., 1995). Burd et al.(1998) observed that both the number of Indian mustard seeds that germinated in a nickelcontaminated soil and the attainable plant size increased by $50 \%-100 \%$ with the addition of K. ascorbata SUD165/ 26 , an associated plant growth-promoting rhizobacteria to the soil in preliminary field trials. de Souza et al. (1999 a) studied phytoremediation of $\mathrm{Se}$ and $\mathrm{Hg}$ in constructed wetlands and found that accumulation of $\mathrm{Se}$ and $\mathrm{Hg}$ are enhanced by rhziobacteria in the wetland plant tissues.

The potential and the exact mechanism of rhizobacteria to enhance phytoremediation of soil heavy metals pollution have recently received some attention (Whiting et al., 2001). Microorganisms have been recently identified as one of the vectors of metal dissemination in soils due to their high sorption capacity. This property appears useful for polluted soils bio-remediation (Guiné et al., 2008).

Conclusion : Due to rapid industrial revolution in last twentieth and in current century, tremendous adverse effects on different sectors (environmental components) have been observed which are not only altering the sectors sequences but also causing human health hazards in their long term association. Albeit, certain metals in their trace values are essential but their higher values have deleterious effects. There are several avenues for heavy metal contamination in agricultural soil but discharge of industrial effluent and sewage in any form (raw / treated) on soil appears as a major cause of heavy metal contamination.

It seems very essential to find out some potent microbial strains for degradation of different heavy metals and also efforts should be made to optimize the different conditions to accelerate the degradation / transformation of heavy metals. Besides this, biotechnological approaches are also essential to enhance microbial degradation efficiency. There is an urgent need to prevent disposal of effluents on agricultural and forest land, both raw and treated effluents. To make assurance free from contamination of soil, it is imperative to prevent disposal of treated effluents because it may cause severe human health hazard if it is translocated in the product. Therefore regular monitoring of treated effluents is the need of the hour for human welfare.

\section{ACKNOWLEDGEMENTS}

Thanks are due to the research fellowship provided by University Grants Commission, New Delhi to the author Mr.Chakresh Pathak.

\section{REFERENCES}

Alloway, B.J. (1990). Cadmium. In: Alloway, B.J. (Ed.), Heavy metals in soils. Blackie and Son Glasgow. pp. 100-121.

Andersson, A. (1979). In: Nriagu, J.O., (Ed.), The Biogeochemistry of Mercury in the Environment, Elsevier, Amsterdam. pp. 79-102.

Anikwe, M.A.N. and Nwobodo, K.C.A. (2002). Long term effect of municipal waste disposal on soil science society of Nigeria held Nov. 21-25, 1999. Bein city Nigeria.

Aydinalp, C. and Marinova, S. (2003). Distribution and forms of heavy metals in some agricultural soils, Polish Journal of Env. Studies, 12 (5) 629-633.

Birley, M. and Lock, K. (1999). A review of health impacts of peri-urban natural resource development. International Health Impact Assessment Research Group, University School of Medicine.

Bissen, M. and Frimmel, F. H. (2000). Speciation of As(III), As (V), MMA and DMA in contaminated soil extracts by HPLC-ICP/MS. Fresenius' Journal of Analytical Chemistry, 367: 51-55.

Brady, N.C. and Weil, R.R. (1999). The nature and properties of soils. 12th ed. Prentice Hall. Upper Saddle River, NJ.

Bradshaw, A. D. (1997). Restoration of mined lands-using natural process. Ecological Engineering, 8, 255-269.

Bumps, J.A. and Aust, S.D. (1989). Biodegradation of DDT [1, 1, 1-trichloro 2, 2-bis (4-chlorophenyl) ethane] by the white rot fungus, Phanerochate chrysosposium. Appl. Environ. Microbiol.,53:2001-2008.

Burd, G.I., Dixon, D.G. and Glick, B.R. (1998). A plant growth-promoting bacterium that decreases nickel toxicityinseedlings. Appl. Environ. Microbiol.,64 (3): 3663-3668. 
Cole, D. C., Diamond, M., Bassil, K. and Heather, J. (2003). Health risk and benefit assessment in UPA. SSA workshop on health risks and benefits of urban and peri-urban agriculture. Nairobi, Kenya.

Cook, P.J. and Freney, R.J. (1988). Sources of cadmium in agriculture. In: Simpson, J., Curnow, B. (Eds.), Cadmium Accumulations in Australian Agriculture. National Symposium, Canberra, 1-2 March 1988, Australian Govt. Publ. Service, Canberra. pp. 4- 19.

Combs, Jr.G.F. and Combs, S.B. (1986).The role of selenium in nutrition. Academic Press, Orlando, FL.

Chang, A., Page, A. and Asano, T., (1995). Developing human health-related chemical guidelines for reclaimed wastewater and sewage sludge applications in agriculture. Geneva, World Health Organization (WHO).

Chen, T. B.,Wong, J.W.C., Zhou, H. Y. and Wong,M.H. (1997). Assessment of trace metal distribution and contamination in surface soils of Hong Kong. Environ. Pollut., 96 (1): 61-68.

Craig, J.R., Rimstidt, J.D., Bonnaffon, C.A., Collins,T.K. and Scanlon, P.F. (1999). Surface water transport of lead at a shooting range. Bull. Environ. Contam. Toxicol., 63:312-319.

de Meeus, C., Eduljee, G. H. and Hutton, M., (2002). Assessment and management of risks arising from exposure to cadmium in fertilizers I. Sci. Total Environ., 291(1-3): 167-187.

de Souza, MP, Huang, CP, Chee, N. and Terry, N. (1999).Rhizosphere bacteria enhance the accumulation of selenium and mercury in wetland plants. Planta, 209 (2):259-263

Dermatas, D. and Meng, X (2003): Utilization of fly ash for stabilization/solidification of heavy metal contaminated soils. Engineering Geology, 2189, 1-18

Dikshit, A. K., Pallamreddy, K., Reddy, L. V. P. and Saha, J. C. (2000). Arsenic in ground water and its sorption by kimberlite tailings. Journal of Environmental Science and Health, 35: 65-85.

Friedland, A.J. (1989). The movement of metals through soils and ecosystem. In: Shaw, A.J. (Ed.). Heavy metal tolerance in plants: Evolutionary aspects. CRC press, Inc, Boca Raton: 7-20.

Feller, K. A. (2000). Phytoremediation of soils and waters contaminated with arsenicals from former chemical warfare installations. In :D. L. Wise, D. J. Trantolo, E. J. Cichon, and U. Stottmeister (Eds.), Bioremediation of Contaminated Soils (pp. 771-786). New York: Marcel Dekker.

Fuller, W.H. (1977). Movement of selected metals, asbestos and cyanide in soil: Application to waste disposal problem. EPA- 600/2-77-020.Solid and hazardous waste research division, U.S. Environmental protection agency, Cincinnati, $\mathrm{OH}$.

Guiné, V., Vitorge, E., Gaudet, J.P., Spadini, L. and Martins,
J.M.F. (2008). Role of bacteria in the accelerated transfer of heavy metals in soils: Advantages for polluted soil bio-remediation.Geophysical Research Abstracts, Vol. 10, EGU2008-A-07874, SRef-ID: 1607-7962/gra/ EGU2008-A-07874.

Gupta, A.K., Sinha, S., Basant, A. and Singh, K.P. (2007). Multivariate analysis of selected metals in agricultural soil receiving UASB treated tannery effluent at Jajmau, Kanpur(India). Bull. Environ. Contam. Toxicol., 79:577582.

Jensen, A. and Bro-Rasmussen, F. (1992). Environmental cadmium in Europe. Rev. Environ. Contam. Toxicol., $125: 101-181$.

Jiménez-Cárceles, F.J., Álvarez-Rogel, J. and Conesa Alcaraz, H.M. (2008). Trace element concentrations in saltmarsh soils strongly affected by wastes from metal sulphide mining areas.Water,Air, Soil Pollution, 188:283295.

Kara, E. E., Pirlak, U. and Ozdilek, H. G. (2004). Evaluation of heavy metals $(\mathrm{Cd}, \mathrm{Cu}, \mathrm{Ni}, \mathrm{Pb}$, and $\mathrm{Zn})$ distribution in sowing regions of potato fields in the province of Nigde, Turkey. Water Air Soil Pollut, 153(1-4): 173-186.

Kabata-Pendias, A. and Pendias, H. (1992). Trace elements in soils and plants, CRC Press, Baton Raton, FL. pp. 365 .

Kovacs, A., Dubbin, W. E. and Tamas, J. ( 2006). Influence of hydrology on heavy metal speciation and mobility in a $\mathrm{Pb}-\mathrm{Zn}$ mine tailing. Environ. Pollut., 141(2): 310 320.

Lasat, M. M. (2002). Phytoextraction of toxic metals: A review of biological mechanism. Journal of Environmental Quality, 31: 109-120.

Lee, B., Pometto, A.L. and Fratzke (1991). Biodegradation of degradable plastic polythene by Phaneochate and Streptomyces species. Appl. Environ. Microbio., 57:678-683.

Lin, T.-H., Huang, Y.-L. and Wang, M.Y. (1998). Arsenic species in drinking water, hair, fingernails, and urine of patients with blackfoot disease. Journal of Toxicology and Environmental Health, Part A, 53:85-93.

Lokeshwari, H. and Chandrappa, G.T. (2006). Impact of heavy metal contamination of Bellandur Lake on soil and cultivated vegetation. Current Science, 91 (5): 622627.

Lopez-Mosquera, M.E., Moiron, C. and Carral, E. (2000). Use of dairy industry sludge as fertilizer for grasslands in northwest Spain: Heavy metal level in the soil and plant. Resource, Conservation and Recycling, 30: 95109.

Mason, B. and Moore, C.B. (1982).Principles of Geochemistry, John Wiley, New York. pp. 344.

Manahan, S. E. (1997). Environmental science and technology, New York: Lewis Publishers.

Masto, R.E., Chhonkar, P.K., Singh, D. and Patra, A.K. 
(2008). Changes in soil quality under long term sewage irrigation in a sub tropical environment. Environ. Geol.

Matsui, M., Nishigori, C., Toyokuni, S., Takada, J., Akaboshi, M. and Ishikawa, M. (1999). The role of oxidative DNA damage in human arsenic carcinogenesis: Detection of 8-hydroxy-2фdeoxyguanosine in arsenic-related Bowen's disease. Journal of Investigative Dermatology, 113: 26-31.

Mayland, H.F., James, L.F., Panter, K.E. and Sonderegger, J.L. (1989). In: Jacobs, L.W. (Ed.), Selenium in Agriculture and the Environment. Soil Sci. Soc. Am. Spec. Pub. No. 23. ASA, SSSA, Madison, WI. pp. 15-50.

McLaughlin, M.J., Tiller, K.G., Naidu, R. and Stevens, D.G., (1996). Review: The behaviour and environmental impact of contaminants in fertilizers. Aust. J. Soil. Res. 34:1-54.

McGrath, Steve P.,Chaudri, Amar, M. and Giller, Ken, E. (1995). Long-term effects of metals in sewage sludge on soils, microorganisms and plants. Journal of Industrial Microbiology and Biotechnology, 14 (2): 94-104.

Merry, R.H., Tiller, K.G. and Alston, A.M. (1983). Accumulation of copper, lead and arsenic in Australian orchard soils. Aust. J.Soil Res., 21: 549-561.

Mishra, A. and Tirpathi, B.D. (2008). Heavy metal contamination of soil, and bioaccumulation in vegetables irrigated with treated wastewater in the tropical city of Varanasi, India. Toxicological \& Environmental Chemistry, 1-11.Retrieved on 24.06.2008 at www.informaworld.com.

Mustafa, K., Sukru, D., Celalettin, O. and Mehmet Emin, A. (2006). Heavy metal accumulation in irrigated soil with wastewater. Ziraat Fakultesi Dergisi, 20 (38):6467.

Nabulo, G., Oryem-Origa, H. and Diamond M, (2006). Assessment of lead, cadmium, and zinc contamination of roadside soils, surface films, and vegetables in Kampala City, Uganda. Environ. Res., 101(1): 42-52.

Norrish, K. (1968). Some phosphate minerals in soils. Trans. 9th Int. Congr. Soil Sci., Adelaide II: 713-723.

Nriagu, J.O. (1978). Lead in soils, sediments and major rock types. In: Nriagu, J.O. (Ed.) The Biogeochemistry of lead in the environment, Part A. Elsevier, Amsterdam. pp. 15-72.

Nyles, C.B. and Ray, R.N. (1999). The nature and properties of soils. $12^{\text {th }} \mathrm{Ed}$. United states of America.pp.743-785.

Ona, L.F., Alberto, A.P., Prudente, J.A. and Sigua ,G.C. (2006): Levels of lead in urban soils from selected cities in the rice-based region of the Philippines. Env. Sci. Pollut. Res., 13 (3) 177-183.

O’Neill, P. (1990). Arsenic. In: Alloway, B.J. (Ed.), Heavy Metals in Soils. John Wiley \& Sons, New York. pp. 8399.
Oliveira, F.C. and Mattiazzo, M.E. (2001). Metais pesados em Latossolo tratado com lodo de esgoto e em plantas de cana-de-açúcar. Scientia Agricola, 58:581-593.

Obrador, A., Rico, M.I., Mingot, J.I. and Alvarej, J.M. (1997). .Metal mobility and potential bioavailability in organic matter-rich soil-sludge mixtures: effect of soil type and contact time. The Science of the Total Environment 206:117-126.

Page, A.L., Bingham, F.T. and Chang, A.C. (1981). Cadmium. In: Lepp, N.W. (Ed.), Effect of Heavy Metal Pollution on Plants. Vol. 1: Effects of Trace Metals on Plant Function. Applied Science, London. pp. 77-109.

Palomo, A and Palacios, M. (2003). Alkali-activated cementitious materials: Alternative matrices for the immobilization of hazardous waste. Part II: Stabilization of chromium and lead. Cem. Con. and Res. 33: 289-298.

Paz-Alberto, AM, Sigua, GC, Baui BG and Prudente, J.A. (2007): Phytoextraction of Lead-Contaminated Soil Using Vetivergrass (Vetiveria zizanioides L.) ogongrass(Imperata cylindrica L.) and Carabaograss (Paspalum conjugatum L.). Env. Sci. Pollut. Res., 14 (7): 498-504.

Peterson, P.J., Benson, L.M., and Zieve, R. (1981) Metalloids. In: Lepp, N.W. (Ed.), Effect of heavy metal pollution on plants, Vol. 1. Applied Science Publ., London. pp. 279-342.

Pichtel, J.K., Kuroiwa and Sawyerr, H.,T.(2000). Distribution of $\mathrm{Pb}, \mathrm{Cd}$ and $\mathrm{Ba}$ in soils and plants of two contaminated sites. Environ. Pollut., 113:35-40.

Qadir, M., Ghafoor, A. and Murtaza, G. (2000). Cadmium concentration in vegetables grown on urban soils irrigated with untreated municipal sewage. Environ. Dev. Sust., 2: 11-19.

Rattan, R.K., Datta, S.P., Chhonkar, P.K., Suribabu, K. and Singh, A.K. (2005). Long term impact of irrigation with sewage effluents on heavy metal content in soils, crops and groundwater- a case study. Agriculture, Ecosystem and Environment 109: 310-322.

Rahmani, H. R. (2007). Use of industrial and municipal effluent water in Esfahan province-Iran. Scientific Research and Essay 2(3):84-88.

Reed, D.T., Tasker, I.R., Cunnane, J.C. and Vandegrift, G.F. (1992). In environmental remediation removing organic and metal ion pollutants. (Ed. G.F.Vandgrift, D.T. Reed and I.R. Tasker) Amer. Chem. Soc., Washington DC.; pp. 1-19.

Sheppard, S. C. (1992). Summary of phytotoxic levels of soil arsenic. Water Air Soil Pollut, 64: 539-550

Sidhu, A.S. and Narwal, R.P. (2004). Interactive effects of organic materials and lead on maize yield and different fractions of lead in soil. Indian J. Ecol.,31 (2):100-103.

Sauerbeck, D. (1993). Conditions controlling the bioavailability of trace elements and heavy metals derived from phosphate fertilizers in soils. In: 
Proceedings of the International IMPHOS Conference "Phosphorus, Life and Environment". Institute Mondial du Phosphate, Casablanca. pp. 419-448.

Simón, M., Oritz, I., Garæia, I., Fernãndez, E., Fernãndez, J. and Dorronsoro, C. (1999). Pollution of soils by the toxic spill of a pyrite mine (Aznalcollar, Spain). Sci. Total Environment, 242:105-115.

Steinnes, E. (1990). Mercury. In: Alloway, B.J. (Ed.), Heavy Metals in Soils. Blackie and Son, Glasgow. pp. 222-236.

Taylor, M. D. (1997). Accumulation of cadmium derived from fertilisers in New Zealand soils. Sci. Total Environ., 208(1-2): 123-126.

Tembo, B. D., Sichilongo, K. and Cernak ,J. (2006). Distribution of copper, lead, cadmium and zinc concentrations in soils around Kabwe town in Zambia. Chemosphere, 63(3): 497-501.

Terzano, R., Spagnuolo, M., Medici, L, Vekemans, B., Vincze, L., Janssens, K. and Ruggiero, P. (2005). Copper stabilization by zeolite synthesis in polluted soils treated with coal fly ash. Environ. Sci. Technol., 39:6280-6287.

USGS (2002): Lead in December 2001. Mineral industry surveys. U.S. Geological Survey Minerals Information
Publications Service 984 National Center. Reston, VA 20192.

Wang, Q.R., Cui, Y.S., Liu, X.M., Dong, Y.T. and Christie, P. (2003). Soil contamination and plant uptake of heavy metals at polluted sites in China. Journal of Environmental Science and Health. 38: 823- 838.

Wenzel, W.W., Adriano, D.C., Salt, D. and Smith, R. (1999). Phytoremediation: A plant-microbe based remediation system. p. 457-508. In D.C. Adriano et al. (ed.) Bioremediation of contaminated soils. American Society of Agronomy, Madison, WI.

Whiting, S.N, de Souza, M.P. and Terry, N. (2001). Rhizosphere bacteria mobilize $\mathrm{Zn}$ for hyper accumulation by Thlaspi caerulescens . Environ. Sci. Technol.35(15):3144-3150.

Xia,H.P.(2004).Ecological rehabilitation and phytoremediation with four grasses in oil shale mined land. Chemosphere, 54: 345-353.

Yang, W.S., Shu, Z.H.Ye, C.Y. Lan and M.H. Wang (2003). Growth and metal accumulation in uitiver and two sespania species as feed/ zinc mine tailing. Chemosphere, 52:1593-1600. 